University of Nebraska - Lincoln

DigitalCommons@University of Nebraska - Lincoln

Faculty Publications from the Department of Electrical \& Computer Engineering, Department Electrical and Computer Engineering

12-4-1996

\title{
Growth of diamond by rf plasma-assisted chemical vapor deposition
}

\author{
Duane E. Meyer \\ University of Nebraska-Lincoln \\ Natale J. lanno \\ University of Nebraska-Lincoln \\ John A. Woollam \\ University of Nebraska-Lincoln, jwoollam1@unl.edu
}

A. B. Swartzlander

Solar Energy Research Institute, Golden, Colorado

A. J. Nelson

Solar Energy Research Institute, Golden, Colorado

Follow this and additional works at: https://digitalcommons.unl.edu/electricalengineeringfacpub

Part of the Electrical and Computer Engineering Commons

\footnotetext{
Meyer, Duane E.; Ianno, Natale J.; Woollam, John A.; Swartzlander, A. B.; and Nelson, A. J., "Growth of diamond by rf plasma-assisted chemical vapor deposition" (1996). Faculty Publications from the Department of Electrical and Computer Engineering. 11.

https://digitalcommons.unl.edu/electricalengineeringfacpub/11
}

This Article is brought to you for free and open access by the Electrical \& Computer Engineering, Department of at DigitalCommons@University of Nebraska - Lincoln. It has been accepted for inclusion in Faculty Publications from the Department of Electrical and Computer Engineering by an authorized administrator of DigitalCommons@University of Nebraska - Lincoln. 


\title{
Growth of diamond by rf plasma-assisted chemical vapor deposition
}

Duane E. Meyer

Natale J. Ianno

John A. Woollam

Department of Electrical Engineering, University of Nebraska, Lincoln, Nebraska 68588-0511

\author{
A. B. Swartzlander \\ A. J. Nelson \\ Solar Energy Research Institute, Golden, Colorado 80401
}

(Received 27 June 1988; accepted 11 August 1988)

A system has been designed and constructed to produce diamond particles by inductively coupled radio-frequency, plasma-assisted chemical vapor deposition. This is a

low-pressure, low-temperature process used in an attempt to deposit diamond on substrates of glass, quartz, silicon, nickel, and boron nitride. Several deposition parameters have been varied including substrate temperature, gas concentration, gas pressure, total gas flow rate, rf input power, and deposition time. Analytical methods employed to determine composition and structure of the deposits include scanning electron microscopy, absorption spectroscopy, scanning Auger microprobe spectroscopy, and Raman spectroscopy.

Analysis indicates that particles having a thin graphite surface, as well as diamond particles with no surface coatings, have been deposited. Deposits on quartz have exhibited optical bandgaps as high as $4.5 \mathrm{eV}$. Scanning electron microscopy analysis shows that particles are deposited on a pedestal which Auger spectroscopy indicates to be graphite. This is a phenomenon that has not been previously reported in the literature.

Keywords: Plasma deposition; Thin film; Optical materials

Materials: C(diamond)

J. Mater. Res., Vol. 3, No. 6, p. 1397. (c) 1996 Materials Research Society 